\title{
COMPARISON OF CO-WORKERS' LEISURE IN SOFIA AND VILNIUS: PERSONAL OCCASIONS
}

\author{
Irma Šidiškienè \\ Department of Ethnology and Anthropology, Lithuanian Institute of History, \\ Vilnius, Lithuania \\ e-mail: irmasidiskiene@gmail.com
}

\begin{abstract}
The article deals with sociocultural interactions in the environment of co-workers. Comparing the co-workers of Sofia and Vilnius cities residents during the informal gathering of personal occasions, we analysed the leisure time of co-workers during the Soviet times and nowadays. The study showed that although the leisure of Vilnius and Sofia, based on the celebrating / honouring of personal occasions, is very similar, although we can observe some differences in the celebration of marriage and childbirth, and in particular, the (not) honouring of funeral occasion.
\end{abstract}

Keywords: co-workers' leisure, job and family life cycle rituals, personal occasions

Each organisation upholds its unique culture, maintained, recreated, and consolidated by means of employees' formal and informal relations, yet also influenced by a wider cultural environment in which the organisation operates. Presumably, co-workers' social and cultural context is manifested in the course of informal gatherings or informal leisure activities where colleagues communicate with fewer restrictions and can celebrate/mark certain occasions. Since 
there are numerous different occasions and festivals, let us split them into two groups. Some celebrations or occasions are related to a person - birthday, name day, or certain important events in a person's life or career - for the sake of this article these occasions will be called personal. Other holidays are official and common, celebrated within the society, for example, Christmas, New Year, profession days, etc. This article will confine to the analysis of personal occasions.

The two cities selected for the research - Vilnius and Sofia - are favourable for comparative analysis as they are capitals of two states (Lithuania and Bulgaria) and, despite significant differences in population, related by their common Soviet/Communist past. On the one hand, people and organisations working in these cities have in a way undergone comparable political and economic changes and are under the influence of similar global processes. On the other hand, they differ in their cultural context (ethnic, religious, and other aspects), therefore it is important to understand how different cultural contexts manifest in co-workers' communities in the two cities. These contexts will be disclosed through the comparison of co-workers' leisure activities in Vilnius and Sofia and analysis of the celebration/marking of different occasions within groups of colleagues. Here celebration is understood as congratulating one another on different occasions (orally or in writing), at times organising a joint festive table, wining and dining (in a modest or solemn way) together. On certain occasions people would receive presents/financial or other kind of support. Research objectives include exhibiting the role of Soviet-time and nowadays' celebrations in co-workers' environment and comparing the manifestations of personal occasions in the environments of Vilnius and Sofia citizens. In the article, celebrations are understood as an occasion to unite the collective together to express the collective (civic, ethnic, professional or other) identity, to construct or strengthen social relations in the collective.

Topics related to co-workers' leisure activities were analysed in the article "Topography of Concepts in the Analysis of Co-workers' Leisure" by Irma Šidiškienè (2014b), whereas other articles of the author were for the most part focused on issues related to profession days (Šidiškienè 2014a; 2016). Ivanka Petrova of the Bulgarian Academy of Sciences researched co-workers' celebrations (studies published in Bulgarian and German languages) in privately-owned companies in the city of Sofia (2001), travel agencies in the city of Belogradchik (2015), etc. To date, no comparative analysis of co-workers' 
celebrations in Bulgaria and Lithuania have been conducted, though Dalia Senvaitytës comparative analysis of collective identity is worth mentioning. The research was aimed at comparing the practices of student celebrations, based on the questionnaire survey of first-year students of Sofia and Plovdiv universities in Bulgaria (50 first-year students at each university were surveyed) and Kaunas Vytautas Magnus University in Lithuania (Senvaityte 2011), however, this shed little light on festivals and occasions typical of co-workers' communities.

Results of Soviet cultural policy that were obvious at the end of the Soviet era can still be felt today, therefore it is important to analyse the introduction of new festivals. Scenarios of such celebrations were described in the methodological guidelines issued by the State Science and Methodology Office of Cultural and Educational Work (later renamed to the Council of Folk Traditions). Books published in the 1960s (Čepienè 1966 n.d.; Petronyte 1966) just like the latest one - "Civilnès apeigos" (Civil Rituals) (1979) promote active involvement of co-workers in various events and celebrations, including family occasions. Celebration traditions in Bulgaria established during the Soviet period were discussed in Diljana Ivanova's (2015) article, though the question of which of these occasions were marked together with co-workers remains unanswered.

The field research conducted by the author in Sofia ${ }^{1}$ was the first step in the perspective of further investigation ${ }^{2}$, and comparison of its data with that of the citizens of Vilnius allows detection of certain social and cultural peculiarities characteristic of co-workers in Sofia. In the course of the field research in Vilnius and later in Sofia, employees of different organisations attributable to different age groups were surveyed with the help of the semi-structured interview. The respondents were asked whether/how they celebrate certain designated occasions with their co-workers and whether there are other celebrations that had not been named. Various festivities and occasions were included in the survey, however, in this article we will dwell on personal celebrations only which have also been split into two groups - occasions for the most part related to certain events at work - job life cycle rituals (celebrations related to the welcoming of a new employee or him/her receiving their first wages, job anniversaries, employee's leaving the company or retiring) and those related to family events - family life cycle rituals (employees' birthdays, weddings, child naming, funerals). These occasions are structured in the figure below: 


\section{Irma Šidiškienẻ}

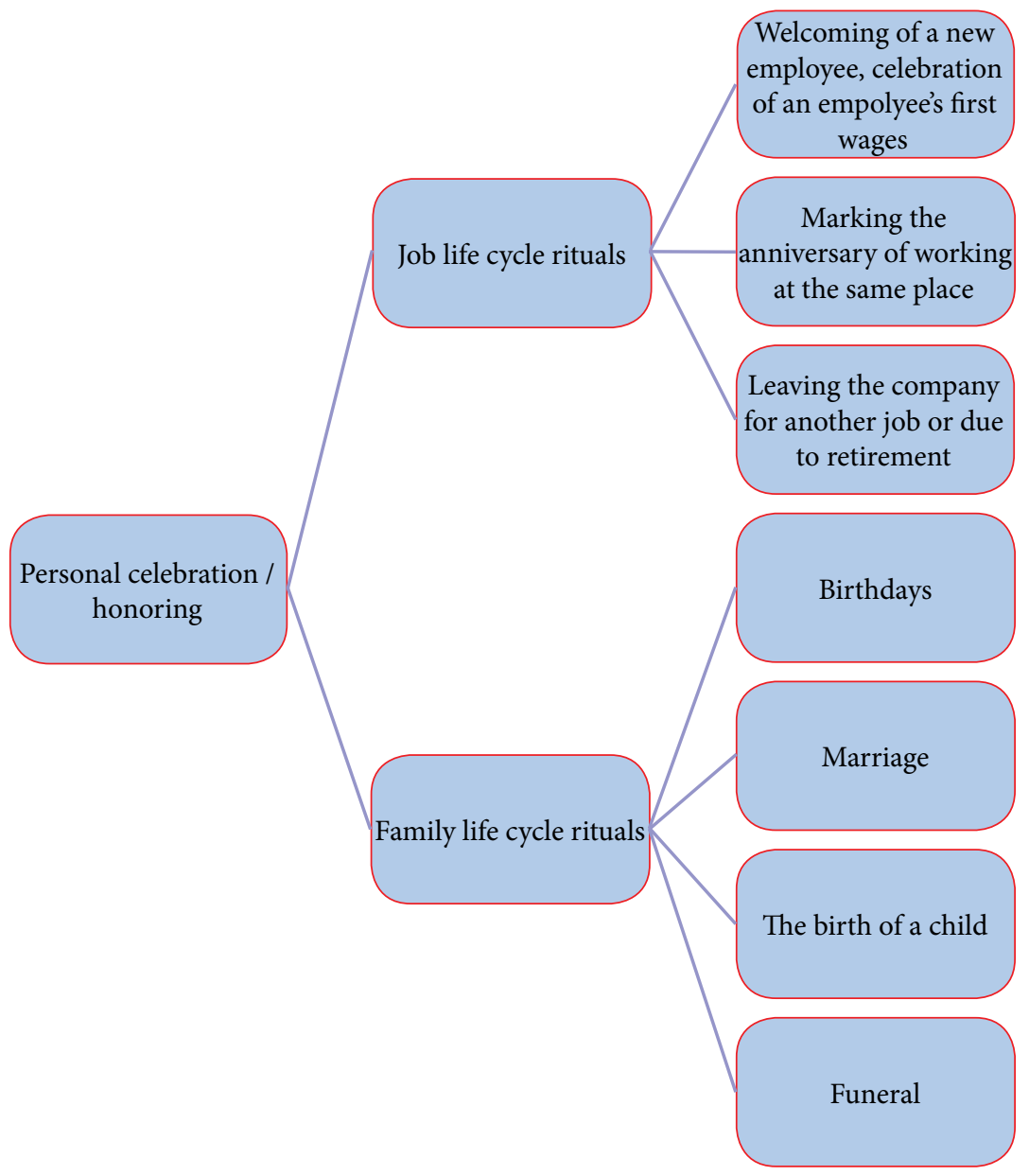

Groups of personal celebrations/occasions. 


\section{Involvement of Co-Workers into Personal Celebrations during the Soviet Era}

In the Soviet times all organisations were bound to follow the orders of the Communist party, therefore in the introduction of new Soviet rituals, organisations were not only utilised to implant such rituals as marking of graduation from educational institutions, welcoming of new employees and organising celebrations with fellow students or co-workers on other occasions, but also attempts were made to react to employees' family events, such as marriage, birth of a child, or funeral. It was believed that celebrations in the public environment of co-workers/fellow students (alongside private family celebrations) retaining the structure of the celebration as well as substituting certain symbolic acts with the new ones that had no religious connotations ${ }^{3}$, could help modify people's behaviour as desired, i.e. distancing them from church rituals and accustoming to the new ones. Books and booklets on civil funeral (Čepiene 1966), marriage and civil naming ceremony (Čepienè \& Gudelis n.d.; Petronytė 1966), civil rituals (Čepienę \& Giedrienè 1969), and the supplemented edition of "Civilinès apeigos" (Čepienè \& Giedrienè 1979) issued by the State Science and Methodology Office of Cultural and Educational Work ${ }^{4}$, tasked with the development and promotion of new festivals, reveal how groups of co-workers were encouraged to participate in their colleagues' personal celebrations. For example, once a child is born and registered at the Civil Registration Office, civil ceremony of naming the child is discussed with the parents and

two weeks before the naming ceremony the Civil Registration Office [...] sends to the parents' employers notification-invitation to participate in the ceremony and congratulate the parents and at the registration office a notice about the naming ceremony is put up so that the public is informed (Čepienè 1979b: 9).

Similar actions are expected on the occasion of marriage (Čepienè \& Gudelis n.d.: 18, 19); moreover, public organisations were encouraged to organise wedding anniversaries and inform the employers and farm managers of those celebrating the anniversary as well as public organizations and participants of the ceremony (Giedriene 1979b: 31) (children and grandchildren) about the celebration. To tell the truth, these anniversaries were successfully adopted and 
became popular in the Soviet times. Particular attention in the abovementioned publication was bestowed on funerals and honouring of the deceased. Here the role of co-workers is particularly important:

Civil funeral is arranged by public organizations, farms, companies and institutions of which the deceased was a member. Co-workers of his/her family members also contribute to the arrangement of the funeral. When a person dies, representatives of the organization visit his/her family, express their condolences and offer their help in arranging the funeral (Giedrienè 1979c: 61).

The said publication points out that not only prominent figures deserve public honouring:

The memory of a humble person is honoured by his/her colleagues and friends. Nowadays death anniversary is more of a family occasion, yet colleagues and friends should not be excluded.

Co-workers, public organizations, and members of the funeral committee help the family arrange and decorate the grave. [...] portrait of the deceased person put up in the red corner of the meeting room is to remind the co-workers of the sad anniversary (Giedrienè 1979c: 74).

It is worth mentioning that in the Soviet times organisations of leisure and promotion of designated occasions based on age groups was bestowed particular attention as there were attempts to introduce initiation ${ }^{5}$ occasions and their celebration (transition from one age group to another: childhood, receiving the first passport, seeing off to the army, retirement), not to mention promotion of working-class festivals and introduction of profession days. Although these new festivals were the focus of attention ${ }^{6}$, not all of them gained popularity at workplaces.

Thus, in the Soviet period the new government-initiated political celebrations were actively promoted and compulsorily observed, and the old family traditions and rites of the ritual year were substituted with the new ones; in addition, attempts were made to discourage people from celebrating certain occasions in the closed family circle, i.e. the custom of the community's participation in certain episodes of family celebrations (wedding, baptism, funeral), typical of rural communities, was being adopted in the city as co-workers were encouraged to take part in such events. On the one hand, this was a prerequi- 
site for the formation of citizen communities, but on the other hand, it helped monitor fellow workers whether they had distanced themselves from "bourgeois prejudice", abandoned religious rituals, etc.

In the period of the Communist rule in Bulgaria, special attention was also bestowed on the modification and governing of the festive culture. According to Diljana Ivanova, alongside mandated meetings and manifestations "people preferred organized holiday banquets associated with the New Year's Day, Babinden, and St. George's Day, while formal dinners and casual entertainment was for the most part associated with personal holidays, such as birthdays, name days, and retirements" (Ivanova 2015: 335). Unfortunately, Ivanova's article does not shed light whether these celebrations were organised within the family, with colleagues or friends. The conducted investigation suggests that the obligatory public holidays and most of the abovementioned occasions were celebrated with co-workers.

\section{Personal Holidays as Celebrated among Co-Workers in Sofia and Vilnius}

In the group of personal occasions, job life cycle rituals are directly related to the formal culture of an organisation. However, despite the effort of Soviet ideologists, in the course of the investigation it became obvious that both surveyed senior citizens of Vilnius and Sofia could hardly remember job life cycle rituals, such as welcoming at the organisation as a new employee (and celebration after receiving the first salary) or congratulating on the fact of working at the same place for a number of years, with the exception of formal honouring of the so-called high achievers and veterans of work.

Vilnius and Sofia citizens witness that occasions related to job life cycle rituals were usually marked in a passive way ${ }^{7}$ and exceptionally when the employee himself/herself mentioned that he/she had received the first salary or was approaching a work anniversary. Colleagues would cheer and orally congratulate their co-worker and sometimes the hero of the day himself/herself would invite colleagues to have a cup of coffee. Similar behaviour is observed in the case of the termination of work agreement, though sometimes the farewell becomes a more solemn occasion. Thus, it can be stated that the said stages of the job life cycle were fragmentary and unexceptional in the respondents' memories. However, in present-day organisations, especially those that actively 
uphold formal management culture, employees' loyalty is highlighted: those who have worked for the company for 5 or 10 years receive acknowledgement letters and souvenirs or such additional benefits as health insurance, etc., yet on the informal level passive marking of colleague's work-related occasions prevails - a Bulgarian respondent born in 1990 maintains that after receiving the first salary "you treat your colleagues to a bar of chocolate, a bag of crisps or something of that kind". Pompous farewell gatherings in honour of employees who were about to retire were best remembered of all job life cycle occasions. It was the retirement in both Vilnius and Sofia that - subject to the retiring employee's will - was usually celebrated formally when all the arrangements were on the organisation, or informally when the employee himself / herself would organise the farewell gathering at a restaurant. Co-workers would normally bring a decent gift - phone, watch, a piece of jewellery, dinner set, souvenirs, or paintings. Of late, modest and informal farewell gatherings on the occasions of retirement become increasingly popular among Vilnius citizens where the retiring employee organises a modest treat including chocolates, cake, and coffee and receives a symbolic gift.

Both formal and informal observation of family life cycle rituals with coworkers was particularly popular in Lithuania in the Soviet times. As it has already been mentioned in the period in question every effort was made to integrate fellow workers into the celebration of each other's personal occasions. Even today colleagues in Vilnius usually greet each other on such occasions as birthdays (jubilees in particular), birth of a child, or wedding. Birthdays are particularly popular among colleagues because, according to Žilvitis Šaknys, they had spread around Lithuania since the 1950s as a natural result of modernisation (Šaknys 2018). In the Soviet times and by the end of the $20^{\text {th }}$ century Vilnius citizens would collect money for a birthday present and would give their colleagues various items of limited supply, household appliances, pieces of jewellery, or books, whereas starting with the restoration of independence, presents became rare on the occasions of ordinary birthdays - co-workers would organise a treat to the hero of the day or invite him/her out to lunch.

Meanwhile in Sofia, though the bigger part of research findings suggests of a similar situation, certain distinctive aspects can be observed. The interviews in Sofia would normally be started with the question: Do you celebrate your birthday together with co-workers? All the answers were positive and the conversation would continue in an emotionally elated manner. Therefore, it 
became obvious that birthdays in Sofia, just like in Vilnius, are the most popular personal (family life cycle) occasion to be celebrated with co-workers. Today, Bulgarians, particularly those working in smaller organisations, continue to collect money for presents. Selection of presents is subject to the preferences and needs of the person whose birthday is celebrated - this information is collected by means of asking those who are in closer contact with the person or the person himself/herself. If the person is not sure what he/she would like to get, colleagues give him/her money instead of the present - "You don't have to buy what the person doesn't need" (fem., b. 1960). Usually something useful for the household, a piece of clothing or jewellery, a book, a souvenir, or even an icon would be bought. In case of jubilees, presents would be more substantial, e.g. a watch. Moreover, each year the way of celebrating should differ, e.g. colleagues would go to the movies, have a meal and a conversation there. In bigger organisations money for presents is seldom collected, at times birthdays are marked in a passive way, i.e. the hero of the day would bring a bag of crisps or a bar of chocolate and offer to the colleagues at his/her workplace (fem. b. 1990). Just one respondent mentioned that it is unusual to celebrate birthdays among her co-workers with the exception of those who want to mark a jubilee and invite his/her colleagues (fem., b. 1953).

The reaction of respondents in Sofia to questions about funerals and partially also to those about weddings was a little unexpected. Here are a few examples. A young respondent was perplexed by the question about weddings - she could hardly relate such personal occasion as marriage with co-workers, therefore asked what kind of research was being conducted. Others just shrugged it off - few people are getting married these days - was their answer. Older respondents remembered that earlier only the closest colleagues would congratulate the newly married couple if they were invited to the wedding (there were cases when all co-workers were invited but not all could attend), then money for the joint present would be collected from all the invitees - "People like socializing and celebrating" (fem., b. 1965); whereas today co-workers tend to act in accordance with the initiative of the bride and the groom: if the newlyweds bring a cake and chocolates to their workplace, it is a sign that they are organising a party at work, in which case colleagues collect money for a more decent present, but if there is no party, there is no present (fem., b. 1990). Thus, the celebration of personal occasions is reserved to the private initiative of the newly married couple. In Vilnius quite the contrary - in the 
Soviet times co-workers would certainly come to congratulate the couple at the marriage registration office or at work when the bride/groom returns after the wedding and brings some treats. Today, though it has been long since the registration office notifications-invitations to co-workers' weddings have last been sent, citizens of Vilnius tend to congratulate their colleagues by gathering at the marriage registration office or the church or at times express their congratulations when the bride/groom returns to job after the wedding and organises a party for the colleagues. Recently marriage has been observed to lose importance among young people (fewer are getting married), therefore the newly married colleague shares his/her impressions and shows photos, thus marking the occasion. At times, a similar situation is observed in case of the birth of a child - colleagues also passively mark the event. Earlier co-workers would arrange with the mother and visit her and the baby at home. Several colleagues, mostly women who were in closer relations with the mother, would visit her but the present would be given on behalf of the whole team.

In Sofia the occasion of the birth of a child not everywhere and not always was "noticed" by fellow workers - after the birth of a child only the closest colleagues would go to visit the mother in 40-days' time: usually "it would be only women who would see the child, other colleagues would not meet him/ her before he/she is 1-year-old" (fem., b. 1957). However, in contrast to the traditions observed in Vilnius, in Sofia the child's father would take a bar of chocolate or a box of sweets to the workplace of his wife. This treat was called "to the health of the child". The mother's colleagues would give the father presents from the co-workers' team. There are cases when prior to the mother-to-be going on maternity leave a party with colleagues is organised and presents are given to the leaving colleague.

As it has already been mentioned, most Bulgarians were surprised by the question about funerals. All the respondents confirmed that co-workers do not attend their colleague's funeral or that of a colleague's relatives, with the exception of those who were close with the person and were informed about the funeral. A respondent's reaction suggests that this is a sensitive issue, as she got irritated once she heard the question and was eager to end the interview saying - that's all, I'm in a hurry - but standing up from the bench, the woman added: "You go out of work [to attend the funeral] and you have to do everything yourself. They say "We're so sorry about that" and that's it. The sorrow is yours. That's it" (fem., b. 1960). It is hard to tell whether this is related with the 
result of the cultural policy of not interfering into the private family space or with the issues pertaining to the dissemination of information. A respondent in Sofia suggested the idea that there were few ways to learn about the death of a former co-worker: "As far as I know in your country and elsewhere obituaries are published in newspapers so that everyone can be informed, but in our country there is no such tradition" (fem., b. 1957). Interviews and observations around the city revealed that other people can learn about a person's death from a notice written on a sheet of paper and put up on the door or gate of the house where the deceased lived or on a tree next to his/her cottage. The date on the notice indicates half year or a year from the person's death and the text invites to pray for the deceased. It appears that information about the deceased is only available at his/her former residence to those who live nearby or accidentally pass by the place.

Data collected in the course of the field research in Vilnius suggest that none of the respondents claimed that he/she had not attended their colleague's funeral. In the Soviet times, following the death of a co-worker or his/her close relative, not only the person's co-workers were informed but the organisation would contribute financially. Today, representatives from the person's company would also come to the memorial service or the funeral bringing flowers or a wreath. Co-workers who wish to support the affected family financially, donate some money handing it over to the relatives, representatives from the organisation attend the memorial service or the funeral.

Thus, in Sofia co-worker's marriage and birth of a child are marked only subject to the initiative of the newlyweds or parents of the new-born, whereas in case of funerals, only those colleagues with whom the deceased was in close relations honour their colleague's family if they happen to learn about the loss.

\section{Conclusions}

The research revealed that the urban culture of post-Soviet capitals was characterised by similar processes. The inquiry into co-workers' leisure exhibited common trends in the celebration of most festivals, especially those related to work life cycle rituals, and formation of unique cultural aspects typical of co-workers' communities. The new practices introduced in the Soviet period would also make an impact on that. Civil rituals developed in Lithuania were integrated into the lives of city dwellers through the encouragement of co- 
workers to become a part of them. On the one hand, an attempt was made to transfer the customs of traditional cultural communities into the city environment, thus creating urban communities, but on the other hand, the Soviet authorities sought to indirectly control the introduction of new festivals into the family environment. In Bulgaria festivals were also modified and their celebration monitored, however, in contrast to Lithuania, this did not affect family occasions and their integration into co-workers' communities. Celebration of such occasions spread among fellow workers to the extent to which they naturally manifested in every-day practice. As a result, we can observe certain distinctions. In Sofia co-workers hardly ever participate in funerals and rarely mark their colleagues' weddings, and the birth of a child is usually celebrated "in absentia", i.e. without the mother and her child. In Vilnius, however, the said occasions are usually marked (always, starting from around 1970s).

The first comparative analysis of the two cities suggests that the official cultural policy of the country has an impact on the cultural manifestations among co-workers (and city dwellers in general) - direct on the formal and partially on the informal. Changes in the cultural policy at the end of the Soviet era resulted in changes in the intensity and intentions of celebrations (marking of occasions), yet the informal celebration remains more or less unaltered.

\section{Notes}

1 When taking part in the Ethnology and Folklore Project of the Lithuanian Institute of History and Bulgarian Academy of Sciences Contemporary Festivity in Bulgaria and Lithuania - from Traditional Culture to Post-Modern Transformations (2015-2017).

2 For more information, Šidiškienè 2016.

3 State Science and Methodology Office of Cultural and Educational Work was in operation in Vilnius issuing various methodological guidelines for the new festivities. These events were supervised and organised by the regional Councils of Folk Traditions which were also tasked with booklet publication and similar activities.

4 Called "iniciatyvinès" in the books most probably due to improper translation from the English word "initiations".

5 Based on the data from literature index item Festivals, Traditions, Customs, and Rituals in Adomavičienè et al. 1988, most articles and publications were dedicated to the introduction, discussion, and promotion of the new rituals, i.e. in the Soviet times, until 1985 , the number of articles on new holidays exceeded that on the old holidays ten times. 
6 Passive marking of the occasion includes oral congratulations, handshakes, greetings sent by e-mail or written on a post card at times followed by a treat to a bar of chocolate or sweets organized by the hero of the day.

\section{References}

Adomavičienè, Irena \& Mamėnienè, Valerija (eds.) 1988. Kultūrinis švietimas. Liaudies tradicijos ir civilines apeigos (literatūros rodyklè) [Cultural Education. Folk Traditions and Civil Rituals (literature index)]. Vilnius: LTSR VRB.

Čepienè, Irena 1966. Civilinès laidotuves (metodinè medžiaga) [Civil Funeral (methodological guidelines)]. Vilnius.

Čepienè, Irena 1979a. Santuokos registravimas [Registration of Marriages]. In: R. Giedrienè (ed.) Civilinés apeigos. Vilnius: Mintis, pp. 18-27.

Čepienè, Irena 1979b. Gimimo registravimas [Registration of Births]. In: R. Giedrienè (ed.) Civilinés apeigos. Vilnius: Mintis, pp. 8-15.

Čepienè, Irena \& Gudelis, D. (eds.) n.d. Sutuoktuvès. Vardynos (metodinė medžiaga) [Marriage. Name Day (methodological guidelines)]. Vilnius.

Čepienè, Irena \& Giedrienè, Rūta (eds.) 1969. Civilinés apeigos [Civil Rituals]. Vilnius: Giedrienè, Rūta 1979a. Perèjimo ị kitą amžiaus grupę apeigos. [Rituals Related to the Transition to another Age Group]. In: Giedrienè, R. (ed.). Civilines apeigos. Vilnius: Mintis, pp. 37-55.

Giedrienè, Rūta 1979b. Sutuoktuvių jubiliejai. [Wedding Anniversaries]. In: Rūta Giedrienè (ed.) Civilines apeigos. Vilnius: Mintis, pp. 30-35.

Giedriené, R. 1979c. Mirusiųu pagerbimas [Honouring of the Deceased]. In: R. Giedrienè (ed.) Civilines apeigos. Vilnius: Mintis, pp. 58-81.

Ivanova, Diljana 2015. Socialist Legacy and Transformations of Cultural Heritage in the Contemporary Forms of the Bulgarian Diaspora in the USA. In: Ana Luleva \& Ivanka Petrova \& Slavia Barlieva (eds.) Contested Heritage and Identities in Post-Socialist Bulgaria. Sofia: Gutenberg Publishing House, pp. 331-358.

Petronytè, R. (ed.) 1966. Auksinès ir sidabrinès vestuvès (metodinè medžiaga) [Gold and Silver Weddings (methodological guidelines)]. Vilnius.

Petrova, Ivanka 2001. Betriebsfeste in Bulgarien heute. Eine ethnologische Analyse. Ethnologia Balkanica, 5, pp. 125-137.

Petrova, Ivanka 2015. Cultural and Natural Heritage and Family Business. The use of Local Resources in the Tourist Context. In: Ana Luleva \& Ivanka Petrova \& Slavia Barlieva (eds.) Contested Heritage and Identities in Post-Socialist Bulgaria. Sofia: Gutenberg Publishing House, pp. 259-280. 


\section{Irma Šidiškienė}

Senvaitytė, Dalia 2011. Kolektyvinio bulgarų ir lietuvių tapatumo bruožai: lyginamoji studentų požiūrio analizė [Characteristics of the Collective Identity of Bulgarians and Lithuanians: The Comparative Analysis of Students' Attitude]. Lituanistica 4 (86), pp. 476-487.

Šaknys, Žilvytis 2008. Vardadienis ir gimtadienis aukštaičių kultūroje: kartografinis tyrimas [Name Day and Birthday in Aukštaitian Culture: Cartographic Research]. Gimtasai kraštas, 1, pp. 21-27.

Šidiškienè, Irma 2014a. Profesinès šventès tyrimų ir medijų lauke [Profession Days in the Field of Research and Media]. Lietuvių katalikų mokslo akademijos metraštis, 38, pp. 225-237.

Šidiškienè, Irma 2014b. Sąvokų topografavimas bendradarbių laisvalaikio tyrime [Topography of Concepts in the Analysis of Co-workers' Leisure]. Lituanistica 3 (97), pp. 212-221.

Šidiškienè, Irma 2016. Profesinio tapatumo stiprinimo praktika: vilniečių profesinè diena [The Practice of Professional Identity-building: The Profession Day of Vilnius Citizens]. Lituanistica, 2 (104), pp. 145-165. 